\title{
The Stimulation by Thrombin of Glucose Oxidation in Human Platelets *
}

\author{
Andrew L. Warshaw, Leonard Laster, $\dagger$ and N. Raphael Shulman \\ (From the Section on Gastroenterology, Metabolic Diseases Branch, and the Clinical Hema- \\ tology Branch, National Institute of Arthritis and Metabolic Diseases, National \\ Institutes of Health, Bethesda, Md.)
}

The interaction of thrombin and blood platelets is required for clot retraction $(2,3)$. Thrombin, possibly by cleaving fibrinogen in the plasma membrane of the platelet $(4,5)$, produces a morphologic change in the membrane (6) and causes platelets to become adherent and aggregate; in the midst of a clot they fasten to fibrin strands (7). It has been suggested that retraction of the fibrin clot is effected by thrombosthenin, an actomyosinlike contractile protein of platelets (8).

Clot retraction requires energy (9), which is apparently derived from glucose metabolism by platelets. In the absence of glucose, retraction will not $\operatorname{occur}(2,10,11)$; in the presence of inhibitors of glycolysis, retraction is impaired $(12,13)$. In studies of the effects of thrombin on platelet metabolism, it has been observed that thrombin increases the utilization $(13,14)$ and production (13) of adenosine triphosphate, the production of lactic acid $(12,13,15)$, and, in the few minutes before aggregation, the utilization of oxygen (16).

Because it seemed likely that the increased oxygen uptake by platelets exposed to thrombin is related to the metabolism of glucose during clot retraction, we have studied the effects of thrombin on the oxidation of glucose by human platelets in vitro. Platelets were incubated with glucose labeled with ${ }^{14} \mathrm{C}$ in the 1 position or in the 6 position, and the influence of thrombin on the production of ${ }^{14} \mathrm{CO}_{2}$ was determined. The results showed that thrombin produces a marked stimulation of glucose oxidation lasting several hours. This stimulation affects glucose oxidation primarily via the

* Submitted for publication June 13, 1966; accepted September 7, 1966.

Part of this work has been published previously in abstract form (1).

$\dagger$ Address requests for reprints to Dr. Leonard Laster, Clinical Center 8N 240, National Institutes of Health, Bethesda, Md. 20014.
Embden-Meyerhof pathway. The biochemical mechanism of the stimulation was investigated.

\section{Methods}

Materials. Purified bovine thrombin, 1 the activity of which was assayed by determining its ability to convert fibrinogen to fibrin (18), was stored in lyophilized form and used within 1 week of rehydration. Substrates ${ }^{2}$ labeled with ${ }^{14} \mathrm{C}$ were tested for radiochemical purity by paper chromatography: at least $98 \%$ of the radioactivity traveled with the authentic compound, and no contaminants were found. Solutions of puromycin dihydrochloride, ${ }^{3}$ adenosine diphosphate (ADP), 4 and ethylenediaminetetraäcetic acid (EDTA) 5 were prepared fresh for each experiment.

Human platelets were isolated daily from $500 \mathrm{ml}$ of blood drawn from fasting donors and mixed with $50 \mathrm{ml}$ of $1.5 \%$ EDTA. All preparatory steps were carried out with siliconized pipettes at $5^{\circ} \mathrm{C}$ in cellulose nitrate vessels. Erythrocytes were removed by centrifugation at $1,400 \times g$ for 4 minutes. The supernatant plasma was centrifuged at $120 \times g$ for 10 minutes to remove leukocytes. The platelets were harvested from the plasma by centrifugation at $1,400 \times g$ for 15 minutes, washed once in $0.85 \%$ saline, and suspended in $0.85 \%$ saline at a final concentration of 1 to $2 \times 10^{\circ}$ platelets per $\mathrm{ml}$. The final platelet suspension contained no aggregates. Platelet counts were performed by phase microscopy. Average erythrocyte and leukocyte contamination was less than 1 cell per 3,000 platelets and was found to contribute no more than $0.1 \%$ of the observed radiochemical yield in the experiments to be described. Experiments were begun within 3 hours after the blood had been obtained.

Experimental procedure. Incubations for determining substrate oxidation were performed in 10-ml Erlenmeyer flasks containing the appropriate labeled substrate; $1.5 \mathrm{ml}$ of fresh Krebs-Ringer bicarbonate buffer (19) (modified to contain one-half of the recommended calcium concentration) containing glucose or other unlabeled substrates; and $0.5 \mathrm{ml}$ of $0.85 \%$ saline in which were dissolved throm-

${ }^{1}$ Generously provided by Dr. Jules Gladner (17), National Institute of Arthritis and Metabolic Diseases.

2 New England Nuclear Corp., Boston, Mass.

3 Nutritional Biochemicals, Cleveland, Ohio.

4 Calbiochem, Los Angeles, Calif.

5 Distillation Products Industries, Rochester, N. Y. 


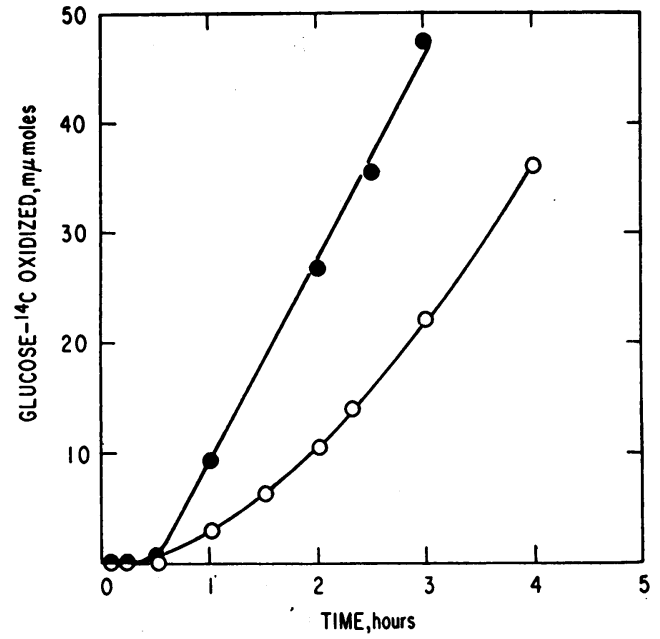

Fig. 1. Oxidation of Glucose-1 $-{ }^{14} \mathrm{C}$ and glucose- $6-{ }^{14} \mathrm{C}$ To ${ }^{14} \mathrm{CO}_{2}$ BY HUMAN Platelets. This experiment is representative of the three that were performed; $10^{\circ}$ platelets were incubated in $5.5 \mathrm{mM}$ glucose with $1 \mu \mathrm{c}$ of glucose$1-{ }^{14} \mathrm{C}(0-\bullet)$ or glucose $-6{ }^{14} \mathrm{C}(\mathrm{O}-\mathrm{O})$.

bin, EDTA, ADP, fibrinogen, or desired combinations of these compounds. Reactions were started by adding 0.5 $\mathrm{ml}$ of platelet suspension and were carried out in a shaker bath at $37^{\circ} \mathrm{C}$ in an atmosphere of $95 \% \quad \mathrm{O}_{2}-5 \% \quad \mathrm{CO}_{2}$. At the end of the incubation, $0.5 \mathrm{ml}$ of Hyamine ${ }^{6}$ was injected through the rubber cap into a polyethylene center well, and the reaction was stopped by injecting $0.4 \mathrm{ml}$ of $6 \mathrm{~N} \mathrm{H}_{2} \mathrm{SO}_{4}$ into the incubation mixture. The flasks were incubated at $37^{\circ} \mathrm{C}$ for an additional 30 minutes to trap ${ }^{14} \mathrm{CO}_{2}$ in the Hyamine. The center well was then transferred to a glass counting vial containing $15 \mathrm{ml}$ of $0.4 \%$ diphenyloxazole (PPO) in toluene for assay of radioactivity in a Packard Tri-Carb liquid scintillation spectrometer. The least active samples had activities at least four times the background, and counting time was selected to yield at least 10,000 counts so that the standard error of the count was less than $1 \%$. Values for counts per minute were converted to disintegrations per minute by the channels ratio method (20). Each incubation was carried out in duplicate, and the results, which usually agreed within $5 \%$ and never differed by more than $10 \%$, were averaged. To calculate the amount of substrate oxidized to $\mathrm{CO}_{2}$ at the labeled position, we divided the value for radioactivity recovered as $\mathrm{CO}_{2}$ by the specific activity of the substrate in the incubation medium. In some cases results are given directly in counts per minute.

Protein synthesis was estimated by a modification of the method of Manchester and Young (21). Platelets were incubated with $1 \mu \mathrm{c}$ of uniformly labeled leucine- ${ }^{14} \mathrm{C}$ (0.004 $\mu$ mole) in $1.5 \mathrm{ml}$ of Krebs-Ringer bicarbonate buffer and $1 \mathrm{ml}$ of $0.85 \%$ saline at $37^{\circ} \mathrm{C}$ for 1 hour in an atmosphere of $95 \% \quad \mathrm{O}_{2}-5 \% \quad \mathrm{CO}_{2}$. Glucose, $5.5 \mathrm{mM}$, and substances to be tested for their effects on protein

6 Packard Instrument Co., Downers Grove, Ill. synthesis were added. The reactions were stopped by addition of an equal volume of $20 \%$ trichloroacetic acid (TCA) containing $10 \mathrm{mM}$ leucine. The precipitate was separated by centrifugation, resuspended in $10 \%$ TCA containing $5 \mathrm{mM}$ leucine, and heated to $90^{\circ} \mathrm{C}$ for 15 minutes. It was then washed three times with the TCAleucine solution and once each with ethanol-ether $(1: 1)$ and ether. The protein precipitate thus obtained was dissolved in $1 \mathrm{ml}$ of Hyamine by warming it at $60^{\circ} \mathrm{C}$ for 10 minutes. The Hyamine solution was dissolved in PPO-toluene for determination of radioactivity as described above. In control experiments the reaction was stopped after 15 seconds and the precipitate treated in the manner described. The value for the radioactivity of these control specimens, about $100 \mathrm{cpm}$ per $10^{\circ}$ platelets, was subtracted from the value of each experimental result. All determinations were performed in duplicate.

Lactic acid was assayed chemically by the method of Barker and Summerson (22) after deproteinization of the incubation mixture with 5\% TCA. Three lithium lactate standards were prepared with each assay, and all determinations were performed in duplicate.

\section{Results}

\section{Oxidation of glucose by platelets}

Incubation of platelets with glucose- $1-{ }^{14} \mathrm{C}$ or glucose-6- ${ }^{14} \mathrm{C}$ led to evolution of ${ }^{14} \mathrm{CO}_{2}$ (Figure 1 ). There was a lag period of approximately $30 \mathrm{~min}$ utes between the start of incubation and the appearance of measurable ${ }^{14} \mathrm{CO}_{2}$, but then ${ }^{14} \mathrm{CO}_{2}$ was generated for at least 3 hours. With an incubation period of 140 minutes the production of ${ }^{14} \mathrm{CO}_{2}$ was

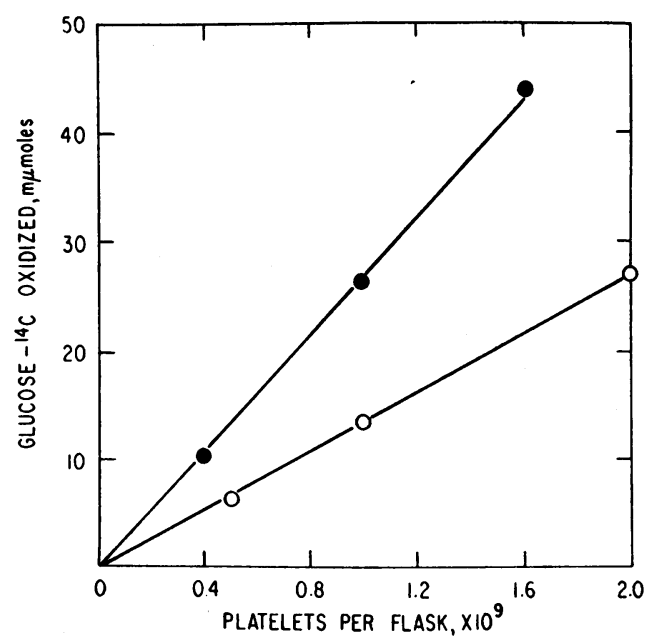

Fig. 2. EFfect of Platelet CONCENTRAtion on GLUCOSE OXIDATION. Platelets were incubated for 140 minutes in $5.5 \mathrm{mM}$ glucose with $1 \mu \mathrm{c}$ of glucose-1 ${ }^{14} \mathrm{C}$ ( -0$)$ or glucose-6- ${ }^{14} \mathrm{C}(\mathrm{O}-\mathrm{O})$. The experiment illustrated is representative of the three performed. 


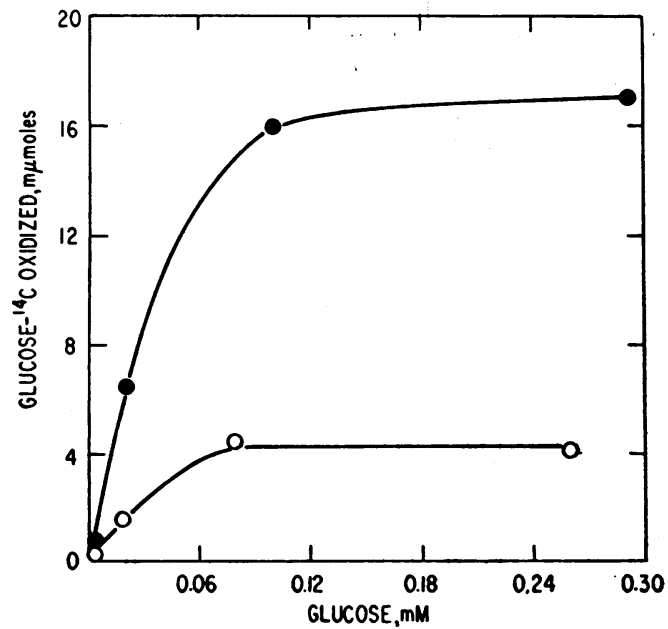

Fig. 3. Relationship between glucose concentraTION IN INCUBATION MEDIUM AND AMOUNT OF GLUCOSE OXIDIZED BY PLATELETS. In this experiment $10^{\circ}$ platelets were incubated for 140 minutes with $1 \mu \mathrm{c}$ of glucose-1-1 ${ }^{14} \mathrm{C}$ ( -

found to be proportional to the quantity of platelets present within the range shown in Figure 2. At low concentrations of glucose, glucose oxidation increased with increasing concentration (Figure 3 ), but in the range from 1 to $20 \mathrm{mM}$ glucose there was no further increase in the amount of glucose oxidized. On the basis of these findings, a standard assay, in which 0.5 to $1 \times 10^{\circ}$ platelets were incubated for 140 minutes in $5.5 \mathrm{mM}$ glucose with approximately $1 \mu \mathrm{c}$ of ${ }^{14} \mathrm{C}$-labeled substrate, was adopted for the oxidation experiments, with exceptions as noted.

The average value for the oxidation of glucose${ }^{1-{ }^{14}} \mathrm{C}$ by human platelets was $42.8 \mathrm{~m} \mu$ moles per $10^{9}$ platelets (Table I, column $a$ ). The average value for the oxidation of glucose- $6-{ }^{14} \mathrm{C}$ was $14.0 \mathrm{~m} \mu$ moles per $10^{9}$ platelets (Table I, column $e$ ). These findings indicate that human platelets can oxidize glucose both by the hexose monophosphate pathway and by the Embden-Meyerhof/citric acid cycle.

\section{Effect of thrombin on glucose oxidation by platelets}

In the presence of thrombin, the platelets agglutinated and their production of ${ }^{14} \mathrm{CO}_{2}$ from

TABLE I

Oxidation of glucose- $1-{ }^{14} \mathrm{C}$ and glucose- $6-{ }^{14} \mathrm{C}$ by human platelets in the absence and presence of thrombin

\begin{tabular}{|c|c|c|c|c|c|c|c|c|}
\hline \multirow[b]{2}{*}{ Experiment- } & \multicolumn{4}{|c|}{ Glucose-1-14 $\mathrm{C}$ oxidized } & \multicolumn{4}{|c|}{ Glucose-6-14 $\mathrm{C}$ oxidized } \\
\hline & $\begin{array}{c}\text { Untreated } \\
\text { platelets } \\
a\end{array}$ & $\begin{array}{c}\text { Platelets + } \\
\text { thrombin* } \\
b\end{array}$ & $\begin{array}{c}\text { Difference } \\
b-a \\
c\end{array}$ & $\begin{array}{c}\text { Stimulation } \\
(c / a) \times 100 \\
d\end{array}$ & $\begin{array}{c}\text { Untreated } \\
\text { platelets } \\
e\end{array}$ & $\begin{array}{c}\text { Platelets + } \\
\text { thrombin* } \\
\quad f\end{array}$ & $\begin{array}{c}\text { Difference† } \\
f-e \\
g\end{array}$ & $\begin{array}{c}\text { Stimulation } \\
(g / e) \times 100 \\
h\end{array}$ \\
\hline & \multicolumn{3}{|c|}{ mumoles $10^{\circ}$ platelets } & $\%$ & \multicolumn{3}{|c|}{ mumoles $11^{\circ}$ platelets } & $\%$ \\
\hline 1 & 51.1 & 59.1 & 8.0 & 12 & 17.8 & 34.9 & 17.1 & 96 \\
\hline 2 & 48.3 & 66.5 & 18.2 & 38 & 12.9 & 34.0 & 21.1 & 164 \\
\hline 3 & 63.0 & 70.4 & 7.4 & 12 & 32.9 & 45.6 & 12.7 & 39 \\
\hline 4 & & & & & 15.9 & 32.4 & 16.5 & 104 \\
\hline 5 & 36.8 & 48.1 & 11.3 & 31 & 12.0 & 26.7 & 14.7 & 122 \\
\hline 6 & 32.6 & 46.1 & 13.5 & 41 & 11.3 & 24.9 & 13.6 & 120 \\
\hline 7 & 30.8 & 38.9 & 8.1 & 26 & 9.1 & 24.4 & 15.3 & 168 \\
\hline 8 & 34.1 & 42.2 & 8.1 & 24 & 9.2 & 22.6 & 13.4 & 146 \\
\hline 9 & 34.0 & 44.3 & 10.3 & 30 & 9.0 & 23.9 & 14.9 & 166 \\
\hline 10 & 71.1 & 93.3 & 22.2 & 31 & 23.9 & 47.7 & 23.8 & 99 \\
\hline 11 & 28.1 & 37.8 & 9.7 & 34 & 8.6 & 22.6 & 14.0 & 162 \\
\hline 12 & 36.4 & 46.3 & 9.9 & 27 & 8.6 & 19.2 & 10.6 & 124 \\
\hline 13 & 46.4 & 58.1 & 11.7 & 25 & 25.3 & 39.2 & 13.9 & 55 \\
\hline 14 & 46.8 & 56.2 & 9.4 & 20 & 17.4 & 35.6 & 18.2 & 104 \\
\hline 15 & 24.7 & 33.2 & 8.5 & 34 & 4.9 & 11.3 & 6.4 & 130 \\
\hline 16 & 51.9 & 62.5 & 10.6 & 20 & 17.9 & 31.4 & 13.5 & 76 \\
\hline 17 & 34.4 & 44.3 & 9.9 & 29 & 9.9 & 23.4 & 13.5 & 138 \\
\hline 18 & 32.8 & 42.1 & 9.3 & 28 & 4.9 & 17.7 & 12.8 & 260 \\
\hline 19 & 41.7 & 47.0 & 5.3 & 13 & 16.0 & 22.1 & 6.1 & 38 \\
\hline 20 & 53.5 & 61.8 & 8.3 & 16 & 16.4 & 31.6 & 15.2 & 93 \\
\hline 21 & 44.5 & 65.9 & 21.4 & 48 & 12.6 & 33.4 & 20.8 & 165 \\
\hline 22 & & & & & 14.1 & 40.8 & 26.7 & 190 \\
\hline 23 & 57.8 & 73.2 & 15.4 & 27 & 12.6 & 30.0 & 17.4 & 138 \\
\hline Mean & 42.8 & 54.0 & 11.2 & 26 & 14.0 & 29.4 & 15.4 & 126 \\
\hline $\mathrm{SD}$ & \pm 11.5 & \pm 13.6 & \pm 4.4 & \pm 10 & \pm 6.5 & \pm 8.8 & \pm 4.5 & \pm 32 \\
\hline
\end{tabular}

* The amount of thrombin added was $1 \mathrm{U}$ per flask in the studies on which this and the remaining Tables are based. The differences listed in columns $c$ and $g$, evaluated by application of Student's $t$ test for paired samples, are significant $(p<.001)$. 


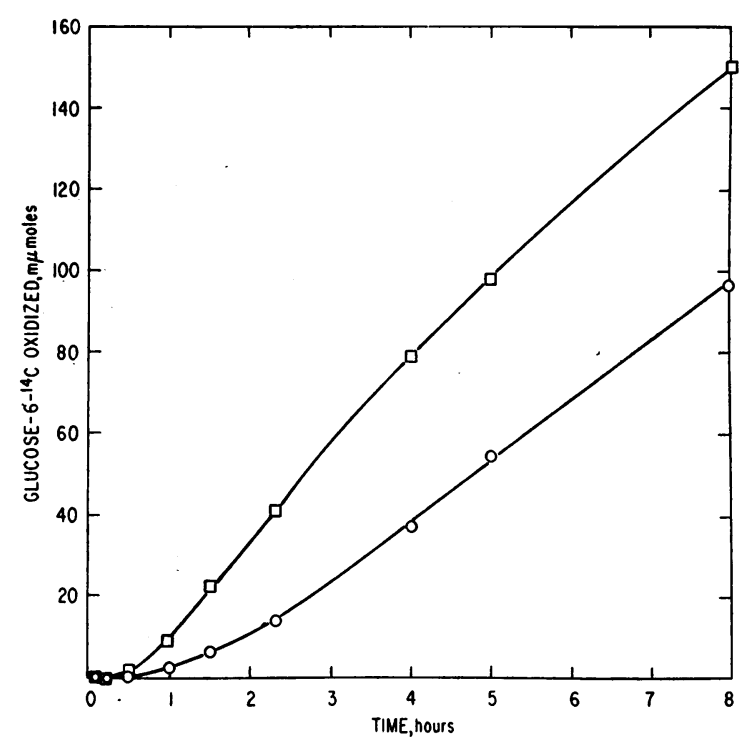

Fig. 4. EFFect OF TIME ON THE STIMUlation BY THROMBIN OF GLUCOSE OXIDATION IN PLATELETS. This experiment is representative of the two performed; the platelets were incubated in $5.5 \mathrm{mM}$ glucose- $6-{ }^{11} \mathrm{C}(1 \mu \mathrm{c})$ with $(\square-\square)$ or without ( $\mathrm{O}-\mathrm{O}) 1 \mathrm{U}$ of thrombin.

labeled glucose increased (Table I, columns $d$ and $h$ ). The stimulation of glucose oxidation reached a maximal value at a thrombin concentration of $1 \mathrm{U}$ per flask, and this concentration was used in the remaining experiments. The effect of time on the stimulation of oxidation was studied with glucose-6- ${ }^{14} \mathrm{C}$ (Figure 4). The lag period before ${ }^{14} \mathrm{CO}_{2}$ generation began in the presence of thrombin was similar to that observed in the absence of thrombin, but the stimulation was apparent as soon as the system began to produce ${ }^{14} \mathrm{CO}_{2}$ and was constant for several hours. At $5.5 \mathrm{mM}$ glucose, oxidation of glucose- $6-{ }^{14} \mathrm{C}$ increased $126 \%$ (range, 38 to $260 \%$ ) in the presence of thrombin, whereas oxidation of glucose- $1-{ }^{14} \mathrm{C}$ increased only $26 \%$ (range, 12 to $48 \%$ ) (Table I, columns $d$ and $h$ ). In each experiment the percentage increase of oxidation of glucose- $6-{ }^{14} \mathrm{C}$ was always greater than twice that of glucose $-1{ }^{14} \mathrm{C}$, but the absolute increase of oxidation of glucose-6- ${ }^{14} \mathrm{C}$ was equal to or slightly greater than that of glucose- $1-{ }^{14} \mathrm{C}$ (Table I, columns $c$ and $g$ ). The approximate equality of the absolute increments produced by thrombin suggests that thrombin acts to stimulate the Embden-Meyerhof pathway but gives no evidence for stimulation of the hexose monophosphate pathway.

At $0.1 \mathrm{mM}$ glucose, the stimulation by thrombin was diminished or abolished (Table II, columns $c$ and $f$ ).

TABLE II

The effect of thrombin on oxidation of hexoses at low concentrations

\begin{tabular}{|c|c|c|c|c|c|c|c|c|}
\hline \multirow[b]{2}{*}{ Substrate } & \multicolumn{4}{|c|}{ Hexose-1" $\mathrm{C}$ oxidized } & \multicolumn{4}{|c|}{ Hexose- ${ }^{14} \mathrm{C}$ oxidized } \\
\hline & $\begin{array}{c}\text { Substrate } \\
\text { concentration }\end{array}$ & $\begin{array}{c}\text { Untreated } \\
\text { platelets } \\
a\end{array}$ & $\begin{array}{c}\text { Platelets }+ \\
\text { thrombin } \\
b\end{array}$ & $\begin{array}{c}\text { Change } \\
\frac{b-a}{a} \times 100 \\
c .\end{array}$ & $\begin{array}{c}\text { Substrate } \\
\text { concentration }\end{array}$ & $\begin{array}{c}\text { Untreated } \\
\text { platelets } \\
d \\
\end{array}$ & $\begin{array}{c}\text { Platelets }+ \\
\text { thrombin } \\
e\end{array}$ & $\begin{array}{c}\text { Change } \\
\frac{e-d}{d} \times 100 \\
f\end{array}$ \\
\hline & mmoles $/ L$ & \multicolumn{2}{|c|}{ mumoles $/ 10^{9}$ platelets } & $\%$ & mmoles $/ L$ & \multicolumn{2}{|c|}{ mumoles $/ 10^{\circ}$ platelets } & $\%$ \\
\hline Glucose- $1-{ }^{14} \mathrm{C}$ & $\begin{array}{l}0.10 \\
0.10 \\
0.02\end{array}$ & $\begin{array}{r}25.1 \\
16.0 \\
6.1\end{array}$ & $\begin{array}{r}24.8 \\
18.1 \\
6.4\end{array}$ & $\begin{array}{l}-1 \\
+13 \\
+5\end{array}$ & $\begin{array}{l}5.5 \\
5.5 \\
5.5\end{array}$ & $\begin{array}{l}30.8 \\
24.7 \\
24.7\end{array}$ & $\begin{array}{l}38.9 \\
33.2 \\
33.2\end{array}$ & $\begin{array}{l}+26 \\
+34 \\
+34\end{array}$ \\
\hline \multirow[t]{2}{*}{ Glucose- $6-{ }^{14} \mathrm{C}$} & $\begin{array}{l}0.08 \\
0.08 \\
0.02 *\end{array}$ & $\begin{array}{r}10.0 \\
4.4 \\
1.6\end{array}$ & $\begin{array}{r}11.8 \\
6.3 \\
1.7\end{array}$ & $\begin{array}{l}+18 \\
+43 \\
+\quad 5\end{array}$ & $\begin{array}{l}5.5 \\
5.5 \\
5.5\end{array}$ & $\begin{array}{l}9.1 \\
4.9 \\
4.9\end{array}$ & $\begin{array}{l}24.4 \\
11.3 \\
11.3\end{array}$ & $\begin{array}{l}+168 \\
+130 \\
+130\end{array}$ \\
\hline & \multicolumn{4}{|c|}{ No glucose in medium } & \multicolumn{4}{|c|}{$5.5 \mathrm{mM}$ glucose in medium } \\
\hline Mannose- $1-{ }^{14} \mathrm{C}$ & $\begin{array}{l}0.05 \\
0.05\end{array}$ & $\begin{array}{l}12.8 \\
15.1\end{array}$ & $\begin{array}{l}12.4 \\
13.5\end{array}$ & $\begin{array}{l}-3 \\
-10\end{array}$ & $\begin{array}{l}0.05 \\
0.05 \\
0.05\end{array}$ & $\begin{array}{l}0.368 \\
0.359 \\
0.244\end{array}$ & $\begin{array}{l}0.433 \\
0.449 \\
0.314\end{array}$ & $\begin{array}{l}+18 \\
+\quad 25 \\
+\quad 28\end{array}$ \\
\hline F ructose-U-14C & $\begin{array}{l}0.16 \\
0.16 \\
0.16\end{array}$ & $\begin{array}{l}2.34 \\
3.64 \\
2.54\end{array}$ & $\begin{array}{l}2.52 \\
4.24 \\
3.86\end{array}$ & $\begin{array}{l}+7 \\
+17 \\
+50\end{array}$ & $\begin{array}{l}0.16 \\
0.16 \\
0.16\end{array}$ & $\begin{array}{l}0.04 \\
0.05 \\
0.06\end{array}$ & $\begin{array}{l}0.16 \\
0.10 \\
0.08\end{array}$ & $\begin{array}{l}+300 \\
+100 \\
+\quad 33\end{array}$ \\
\hline Galactose-1-14 $\mathrm{C}$ & 0.05 & 7.3 & 5.1 & -30 & $\begin{array}{l}0.05 \\
0.05 \\
0.05\end{array}$ & $\begin{array}{l}2.36 \\
1.56 \\
1.72\end{array}$ & $\begin{array}{l}1.33 \\
0.97 \\
0.99\end{array}$ & $\begin{array}{l}-44 \\
-38 \\
-42\end{array}$ \\
\hline
\end{tabular}

* Two-tenths $\mu \mathrm{c}{ }^{14} \mathrm{C}$ was used; all other reaction mixtures contained $1 \mu \mathrm{c}$ of ${ }^{14} \mathrm{C}$. 
TABLE III

The effect of thrombin on oxidation of mannose- $1-{ }^{14} C$, fructose- $U-{ }^{14} C$, and galactose- $1-{ }^{14} C$ by human platelets*

\begin{tabular}{|c|c|c|c|c|c|c|}
\hline \multirow{3}{*}{ Substrate } & \multicolumn{3}{|c|}{ Hexose- ${ }^{14} \mathrm{C}$ oxidized (no glucose in medium) } & \multicolumn{3}{|c|}{ Hexose- ${ }^{14} \mathrm{C}$ oxidized ( $5.5 \mathrm{mM}$ glucose in medium) } \\
\hline & $\begin{array}{l}\text { Untreated } \\
\text { platelets }\end{array}$ & $\underset{\text { thrombin }}{\text { Platelets }}+$ & $\begin{array}{c}\text { Change } \\
\frac{b-a}{a} \times 100\end{array}$ & $\begin{array}{l}\text { Untreated } \\
\text { platelets }\end{array}$ & $\underset{\text { thrombin }}{\text { Platelets }}+$ & 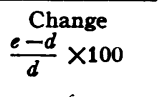 \\
\hline & $a$ & $b$ & $c$ & $d$ & e & $f$ \\
\hline & \multicolumn{2}{|c|}{ m $\mu$ moles $/ 10^{\circ}$ platelets } & $\%$ & \multicolumn{2}{|c|}{ mumoles $/ 10^{\circ}$ platelets } & $\%$ \\
\hline Mannose- $1-{ }^{14} \mathrm{C}$ & $\begin{array}{l}26.1 \\
68.1 \\
42.3\end{array}$ & $\begin{array}{l}36.0 \\
81.5 \\
51.7\end{array}$ & $\begin{array}{l}+38 \\
+20 \\
+22\end{array}$ & $\begin{array}{l}12.0 \\
29.8 \\
20.8\end{array}$ & $\begin{array}{l}17.9 \\
42.0 \\
24.4\end{array}$ & $\begin{array}{l}+50 \\
+41 \\
+18\end{array}$ \\
\hline Fructose-U- ${ }^{14} \mathrm{C}$ & $\begin{array}{l}27.5 \\
50.2 \\
38.4\end{array}$ & $\begin{array}{l}37.2 \\
75.8 \\
43.0\end{array}$ & $\begin{array}{l}+35 \\
+51 \\
+12\end{array}$ & $\begin{array}{l}1.75 \\
1.5 \\
0\end{array}$ & $\begin{array}{l}2.1 \\
2.5 \\
0\end{array}$ & $\begin{array}{r}+20 \\
+66 \\
0\end{array}$ \\
\hline Galactose $-1-{ }^{14} \mathrm{C}$ & $\begin{array}{l}11.1 \\
19.8 \\
12.2\end{array}$ & $\begin{array}{r}9.3 \\
13.6 \\
6.7\end{array}$ & $\begin{array}{l}-16 \\
-31 \\
-45\end{array}$ & $\begin{array}{r}4.2 \\
10.3 \\
6.2\end{array}$ & $\begin{array}{l}3.1 \\
6.5 \\
3.1\end{array}$ & $\begin{array}{l}-27 \\
-37 \\
-50\end{array}$ \\
\hline
\end{tabular}

${ }^{*}$ The reaction mixtures contained the appropriate hexose at $5.5 \mathrm{mmoles}$ per $\mathrm{L}$ with $1 \mu \mathrm{c}$ of ${ }^{14} \mathrm{C}$. Glucose at 5.5 mmoles per $\mathrm{L}$ was also present where indicated.

\section{Studies of other substrates and intermediates}

To localize further the site of stimulation of glucose oxidation, we investigated the effect of thrombin on the metabolism of other hexoses and their intermediates.

Other hexoses. At a concentration comparable to that at which glucose was tested, 5.5 mmoles per L, mannose-1-14 $\mathrm{C}$ and fructose- $\mathrm{U}-{ }^{14} \mathrm{C}$ (Table III, column $a$ ) were oxidized by platelets at about the same rate as was glucose- $-1{ }^{14} \mathrm{C}$. In the presence of equimolar glucose, the utilization of mannose was halved and that of fructose was nearly abolished (Table III, column $d$ ). The oxidation of mannose and fructose was stimulated about $30 \%$ by thrombin, whether or not glucose was present (Table III, columns $c$ and $f$ ).

At low concentrations of fructose or mannose, their oxidation was much less (Table II, column a) than at 5.5 mmoles per L, especially in the presence of glucose (Table II, column $d$ ). At these low substrate levels stimulation by thrombin of mannose oxidation was abolished, and stimulation of fructose oxidation was somewhat diminished (Table II, column $c$ ); in both cases the presence of glucose seemed to enhance the stimulation by thrombin (Table II, column $f$ ).

These results show that mannose, fructose, and glucose were each oxidized by platelets and that the oxidation of each was stimulated by thrombin. In particular, platelets exposed to thrombin increased their oxidation of glucose- $1-{ }^{14} \mathrm{C}$ by 11.2 m $\mu$ moles (Table I, column $c$ ), of mannose- $1-{ }^{14} \mathrm{C}$ by $11 \mathrm{~m} \mu$ moles (Table III, column $b$ ), and of fructose-U $-{ }^{14} \mathrm{C}$ by $13 \mathrm{~m} \mu$ moles (Table III, column $b)$. These findings are of further interest since others have found that addition of thrombin to platelets leads to clot retraction (2) and increased lactic acid production (15) in the presence of glucose or mannose, but not of fructose.

Galactose, too, was oxidized by platelets. At 5.5 mmoles per $\mathrm{L}$, oxidation of galactose- $1{ }^{14} \mathrm{C}$ (Table III, column $a$ ) by untreated platelets was comparable to that of glucose- $-6^{-14} \mathrm{C}$. In the presence of thrombin, however, oxidation of galactose$1{ }^{14} \mathrm{C}$ was inhibited approximately $30 \%$ (Table III, column $c$ ). Inhibition was also observed at a galactose concentration of 0.1 mmole per $\mathrm{L}$ (Table II, column $c$ ). In the presence of glucose, inhibition by thrombin of galactose oxidation did not significantly increase (Table II, column f; Table III, column $f$ ).

3-Carbon intermediates. The oxidation of pyruvate was investigated to determine whether thrombin affects the metabolism of intermediates in glucose oxidation. At $5 \mathrm{mM}$ pyruvate, in the presence or absence of glucose, oxidation of pyruvate-1-14 C (Table IV, columns $a$ and $d$ ) was considerably greater than oxidation of glucose- ${ }^{14} \mathrm{C}$ at a comparable concentration. In the presence of glucose, the oxidation of pyruvate- $1-{ }^{14} \mathrm{C}$ by thrombin-treated platelets was about $30 \%$ less than by untreated platelets (Table IV, column $c$ ). In the absence of glucose, thrombin inhibited pyruvate- 


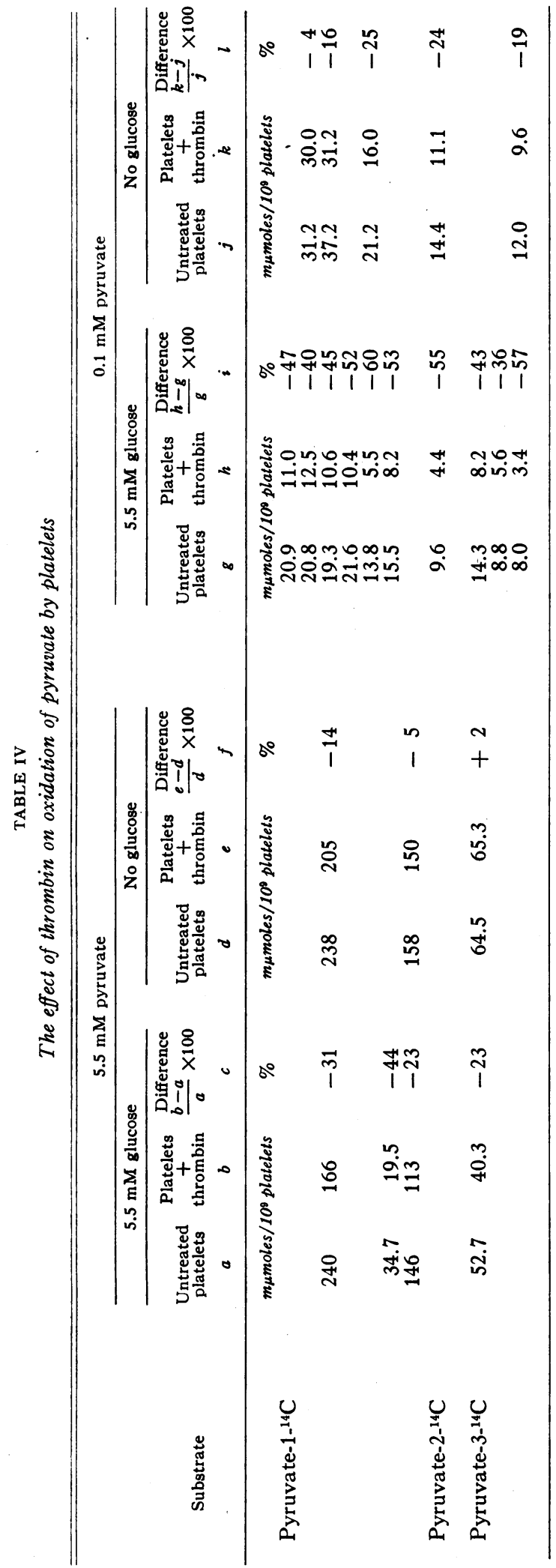

$1{ }^{14} \mathrm{C}$ oxidation to a lesser degree (Table IV, column $f$ ). Even at low concentrations of pyruvate- $1-{ }^{14} \mathrm{C}$, both the inhibition of pyruvate oxidation by thrombin and the enhancement of the inhibition in the presence of glucose were manifest (Table IV, columns $i$ and $l$ ). Similar results were obtained with pyruvate labeled in the 2 - and 3 -carbon positions (Table IV). These findings strongly indicate that thrombin stimulates the oxidation of glucose by platelets by influencing one or more processes earlier in the metabolic sequence than the ones in which pyruvate participates.

Lactic acid production by untreated and thrombin-treated platelets during an 8-hour incubation continued for the entire period (Figure 5). In the presence of thrombin, lactic acid production was greater than in the absence of thrombin; the stimulatory effect of thrombin began immediately and appeared to diminish or end within 30 minutes. Thus, the stimulation of glycolysis was primarily an early and transient phenomenon in contrast to the longer-lasting enhancement of glucose oxidation.

Orotic acid. The conversion of orotic acid to uridine $5^{\prime}$-phosphate involves the decarboxylation of orotidine 5'-phosphate. This reaction was studied to see whether thrombin affects reactions un-

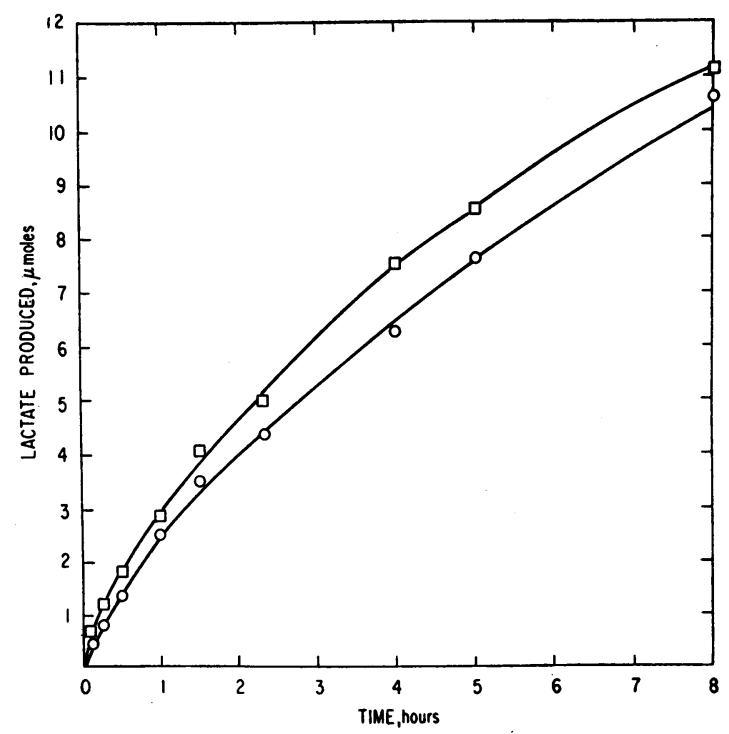

Fig. 5. Lactate production by platelets in the ABSENCE OR PRESENCE OF THROMBIN. The platelets were incubated in $5.5 \mathrm{mM}$ glucose with $(\square-\square)$ or without (O-O) $1 \mathrm{U}$ of thrombin. These data were obtained from the same experiment depicted in Figure 4 but are representative of the two performed. 
TABLE V

The effect of puromycin on the stimulation of glucose oxidation by thrombin and on protein synthesis in platelets*

\begin{tabular}{|c|c|c|c|c|c|c|c|}
\hline \multirow{3}{*}{ Puromycin } & \multicolumn{6}{|c|}{ Glucose oxidation } & \multirow{3}{*}{$\begin{array}{c}\text { Protein synthesis } \\
\begin{array}{c}\text { Incorporation of } \\
\text { leucine-U-14C }\end{array} \\
\begin{array}{c}\text { Untreated platelets } \\
\mathrm{g}\end{array}\end{array}$} \\
\hline & \multicolumn{3}{|c|}{${ }^{14} \mathrm{CO}_{2}$ from glucose-1 ${ }^{14} \mathrm{C}$} & \multicolumn{3}{|c|}{${ }^{14} \mathrm{CO}_{2}$ from glucose-6-14 $\mathrm{C}$} & \\
\hline & $\begin{array}{c}\text { Untreated } \\
\text { platelets } \\
a\end{array}$ & $\begin{array}{c}\text { Platelets }+ \\
\text { thrombin } \\
b\end{array}$ & $\begin{array}{c}\text { Difference } \\
\frac{b-a}{a} \times 100 \\
c\end{array}$ & $\begin{array}{c}\text { Untreated } \\
\text { platelets } \\
d\end{array}$ & $\begin{array}{c}\text { Platelets }+ \\
\text { thrombin } \\
e\end{array}$ & $\begin{array}{c}\text { Difference } \\
\frac{e-d}{d} \times 100 \\
f\end{array}$ & \\
\hline $\begin{array}{l}m M \\
0 \\
0.1 \\
1.0\end{array}$ & $\begin{array}{l}c p m / 10 \\
2,539 \\
2,320 \\
1,810\end{array}$ & $\begin{array}{r}\text { platelets } \\
3,467 \\
2,980 \\
2,303\end{array}$ & $\begin{array}{l}\% \\
+36 \\
+29 \\
+27\end{array}$ & $\begin{array}{l}\text { cpm/1 } \\
592 \\
535 \\
236\end{array}$ & $\begin{array}{r}\text { platelets } \\
1,508 \\
1,175 \\
430\end{array}$ & $\begin{array}{c}\% \\
+154 \\
+120 \\
+83\end{array}$ & $\begin{array}{c}c p m / 10^{\circ} \text { platelets } \\
6,600 \\
1,090 \\
304\end{array}$ \\
\hline
\end{tabular}

* The experiment shown is representative of the four performed. Glucose oxidation was determined according to the standard assay. Protein synthesis was estimated by determination of leucine-U ${ }^{14} \mathrm{C}$ incorporated into trichloroacetic acid-precipitable material.

related to glucose oxidation. In two experiments under the conditions of the standard assay, ${ }^{14} \mathrm{CO}_{2}$ production from $0.03 \mathrm{mM}$ orotic acid-7- ${ }^{14} \mathrm{C}$ (carboxyl labeled) was not significantly altered by the presence of thrombin.

\section{Other studies on the stimulation by thrombin}

Puromycin. Puromycin, an inhibitor of protein synthesis, was tested for possible effect on the stimulation by thrombin of glucose oxidation in platelets (Table V). At $0.1 \mathrm{mM}$ puromycin, incorporation of leucine-U-14C into TCA-precipitable material was inhibited by more than $80 \%$, whereas the stimulation by thrombin of glucose oxidation was only slightly diminished. At 1.0 $\mathrm{mM}$ puromycin, which inhibited incorporation of leucine-U- ${ }^{14} \mathrm{C}$ by $95 \%$, both glucose oxidation in platelets and the stimulation of glucose oxidation produced by thrombin were halved. Thus, even at concentrations high enough to impair glucose oxidation and almost to obliterate protein synthesis in platelets, puromycin lessened but did not entirely prevent the stimulation by thrombin.

Aggregating agents. To test whether the physical state of aggregation per se in some way produced the metabolic changes observed in platelets agglutinated by thrombin, we studied the effects of other aggregating agents. ADP agglutinates platelets but in a readily reversible fashion not accompanied by viscous metamorphosis $(23,24)$. No alteration of glucose oxidation occurred in the presence of ADP at $0.1,0.4$, or 10 mmoles per L. Since fibrinogen has been implicated in the agglutination of platelets by ADP (25) and since in one report (26) the combination of $\mathrm{ADP}$ and fibrinogen was said to cause increased lactate production by platelets, $0.1 \mathrm{mM}$ ADP was tested with $0.2 \mathrm{mg}$ per $\mathrm{ml}$ fibrinogen in our system. As with $\mathrm{ADP}$ alone, the combination did not stimulate glucose oxidation. ADP $(10 \mathrm{mM})$ had no effect on the stimulation of glucose oxidation by thrombin.

Human serum is believed to agglutinate platelets by virtue of its thrombin content. In our studies $0.1 \mathrm{ml}$ of serum consistently agglutinated platelets but failed to stimulate glucose-6- ${ }^{14} \mathrm{C}$ oxidation in eight of twelve experiments. Oxidation of glucose$1{ }^{-14} \mathrm{C}$ was not stimulated in any of four experiments and was depressed in two. Addition of $0.5 \mathrm{ml}$ of serum depressed glucose- $6-{ }^{14} \mathrm{C}$ oxidation in three of four experiments and depressed glucose- $1-{ }^{14} \mathrm{C}$ in all four.

It is apparent from the experiments with both ADP and serum that aggregation per se did not lead to stimulation of glucose oxidation in platelets. In addition, the finding of unchanged or even depressed glucose oxidation in platelets agglutinated by serum raises the possibility that something other than thrombin is responsible for the agglutinating properties of serum. Alternatively, it may be that critically small amounts of thrombin in serum alter the platelet membrane without altering metabolism of glucose, or that there is an inhibitor of glucose oxidation as well as a stimulator (thrombin) in serum.

$E D T A$. EDTA, which prevented agglutination of platelets by thrombin, was tested for its effect on the stimulation of glucose oxidation by thrombin. The results differed, depending upon whether EDTA was added to the incubation medium before, after, or concomitant with addition of throm- 


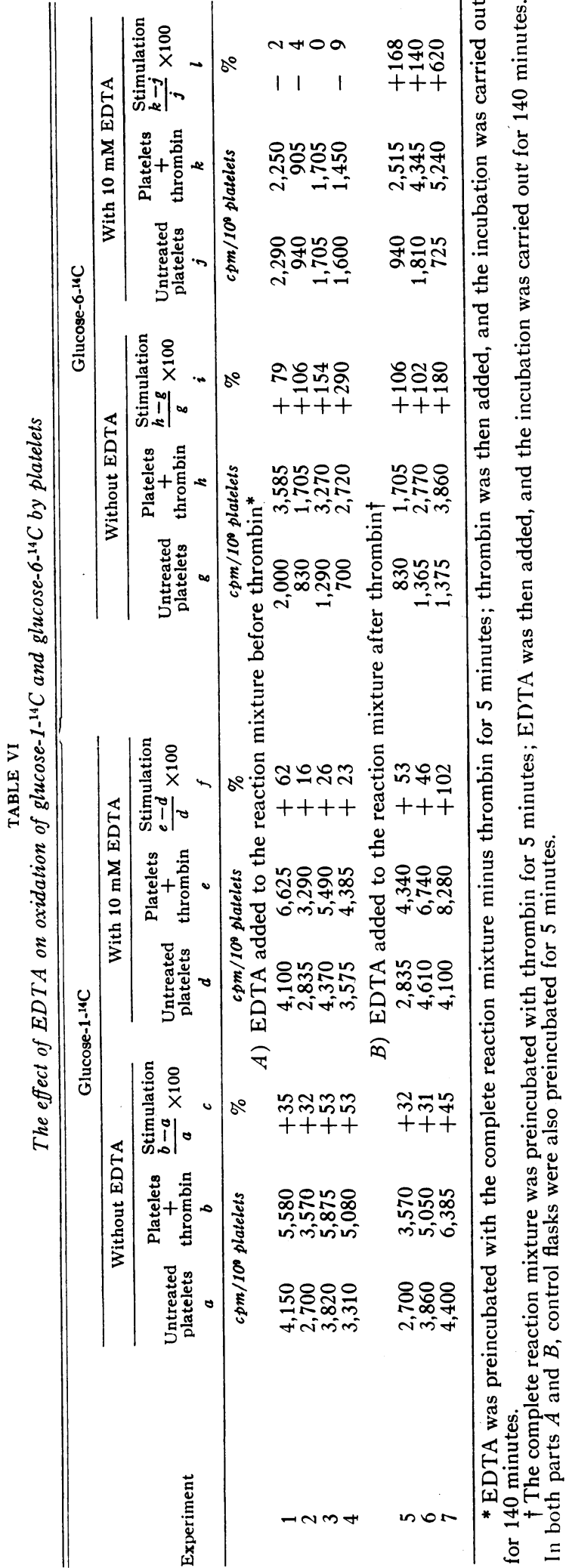

bin. When the EDTA was added 5 minutes before thrombin, stimulation by thrombin of oxidation of glucose-1-14 $\mathrm{C}$ occurred (Table VI, part $A$, columns $c$ and $f$ ), but stimulation of oxidation of glucose-6- ${ }^{14} \mathrm{C}$ was prevented (Table VI, part $A$, columns $i$ and $l$ ). These observations demonstrate that in the presence of EDTA thrombin stimulates the hexose monophosphate pathway but not the Embden-Meyerhof pathway.

When EDTA was added 5 minutes after thrombin, the stimulation of oxidation of both glucose${ }^{1-{ }^{14}} \mathrm{C}$ and glucose- $6-{ }^{14} \mathrm{C}$ was increased in comparison to the stimulation by thrombin alone (Table VI, part $B$, columns $c$, $f$, $i$, and $l$ ). Although EDTA might be acting by a mechanism unrelated to the chelation of divalent cations, the enhancement by EDTA of the effect of thrombin suggests that divalent cations are involved in the stimulation of glucose oxidation.

When EDTA and thrombin were added simultaneously, a variable and inconstant mixture of blocking and stimulation occurred.

\section{Discussion}

Platelets exposed to thrombin effect clot retraction $(2,3)$, a process believed to require energy production from glucose (9-11). It has long been known that platelets possess both oxidative (27) and glycolytic activity (28), but glycolysis has generally been considered the major source of energy in both resting (29) and retracting (13) platelets. One-half of the glucose metabolized by resting platelets is recovered as pyruvic and lactic acids and one-fifth as $\mathrm{CO}_{2}$ and water (30). Although more glucose may be metabolized to lactic acid than oxidized, oxidation produces far more ATP per mole of glucose and, as has been suggested (31), would seem to be the more important source of energy in platelets.

Glucose oxidation in these studies was measured by assay of ${ }^{14} \mathrm{CO}_{2}$ evolved from labeled glucose. A 30-minute lag period was observed between the start of incubation and the generation of detectable ${ }^{14} \mathrm{CO}_{2}$, but no such lag occurred in production of lactate, which was measured chemically. However, the lag period was a constant characteristic of both untreated and thrombin-treated platelets, with either glucose- $1-{ }^{14} \mathrm{C}$ or glucose- $6-{ }^{14} \mathrm{C}$, and the in- 
ferences to be discussed are based on observations made after the onset of ${ }^{14} \mathrm{CO}_{2}$ evolution.

Platelets in vitro oxidized glucose for at least 8 hours, and thrombin stimulated this oxidation for several hours. Since thrombin increased the oxidation of glucose- $6-{ }^{14} \mathrm{C}$ as much or more than that of glucose- $1-{ }^{14} \mathrm{C}$, it is likely that the stimulation of glucose oxidation by thrombin occurs largely and possibly entirely via the EmbdenMeyerhof pathway. Lactic acid formation also increased, but the increment was primarily an early phenomenon followed by a return to the normal rate of production during the remainder of the 8-hour test period. These findings agree with other reports of sudden increments in lactic acid production on exposure of platelets to thrombin $(11,13,15,26)$. Bettex-Galland and Lüscher (13), however, found that glycolytic activity, although initially stimulated, ceased entirely by 30 minutes, and that oxygen uptake by platelets exposed to thrombin actually decreased. It should be noted that in their studies they used 24-hourold platelets, and it is known from the data of others $(15,32,33)$ and from our own unpublished observations that platelets even 1 day old have altered basal oxidation rates and responses to thrombin, as well as diminished ATP $(15,34)$ and glycogen stores (35). With fresh platelets Hussain and Newcomb (16) demonstrated with an oxygen electrode that platelets exposed to thrombin immediately begin to take up oxygen 11 times faster than untreated platelets; once clumping occurred, their measurements ceased because of technical limitations.

Our findings and those of Hussain and Newcomb (16) thus show that thrombin, which causes platelets to retract a clot, produces an increase in oxidative metabolism by platelets. The coincidence of these two effects suggests that oxidative processes contribute to the energy production required for clot retraction. Although Bettex-Galland and Lüscher (13) found that inhibition of platelet respiration with Victoria blue did not impair clot retraction and stated that oxidative metabolism is not important for clot retraction, their observations show only that platelets are capable of functioning for a limited time on glycolysis alone but do not exclude participation by oxidative pathways in the absence of exogenous inhibitors.
We have investigated the site of thrombin's action on the biochemical pathways of glucose oxidation by testing the effect of thrombin on the oxidation of other hexoses and pyruvate. The fact that the oxidation of pyruvate, unlike that of glucose, was not stimulated and was, in fact, markedly inhibited by thrombin suggests that thrombin acts on a process or processes earlier in the sequence of glucose oxidation than the point at which pyruvate enters the pathway. The dependence of the inhibition on the presence of exogenous glucose suggests that the proposed stimulation of the earlier process leads to formation of increased quantities of glucose metabolites that either inhibit utilization of labeled pyruvate or, by diluting metabolic pools, decrease their specific activity.

Thrombin stimulated the oxidation of mannose and fructose by platelets. Since the carbon skeletons of mannose and fructose enter the glucose oxidation sequence as fructose 6-phosphate, the reaction stimulated by thrombin might lie between fructose 6-phosphate and pyruvate. The present experiments neither prove nor disprove this hypothesis. Alternatively, a step common to glucose, mannose, and fructose might be affected. Both transport of substrate into the platelet and phosphorylation by hexokinase are possibilities.

In contrast to the oxidation of the other hexoses, galactose oxidation in thrombin-treated platelets was inhibited. We were unable to demonstrate glucose dependence for the inhibition of galactose oxidation by thrombin. It may be that this inhibition represents a second effect of thrombin, unrelated to its stimulation of glucose oxidation. If so, the inhibition of galactose oxidation by thrombin would not clarify its action on glucose oxidation.

Thrombin, a proteolytic enzyme, is believed to cleave a fibrinogen-like constituent of the platelet membrane $(4,5)$. This change in the platelet membrane renders it more permeable to serotonin, $\mathrm{ADP}$, protein, and ions such as potassium and calcium $(33,36)$, but the increased permeability may be relatively specific, since quite different proportions of various intracellular substances escape (33). If the oxidative pathway for glucose were unsaturated due to limited transport of substrate across the cell membrane, reduction by thrombin of the relative barrier to the entry of 
glucose would allow its increased oxidation. Against this hypothesis may be the fact that a 20 -fold increase in glucose concentration in the incubation medium did not increase glucose oxidation.

Waller, Löhr, Grignani, and Gross (30) found that hexokinase is rate limiting among glycolytic enzymes in platelets. Since hexokinase in other mammalian tissues $(37,38)$ phosphorylates glucose, fructose, and mannose but not galactose to any appreciable extent, stimulation of this enzyme by thrombin could explain the observed increases in oxidation of glucose, mannose, and fructose and the absence of stimulation of galactose oxidation. Substantiation of this possibility would entail determination of the substrate specificity of platelet hexokinase and assay of hexokinase activity in untreated and thrombin-treated platelets. From our evidence it is clear that the stimulation of glucose oxidation occurs earlier in the sequence than pyruvate, but the specific site of stimulation remains undefined.

If thrombin does stimulate one or more enzymatic reactions, the stimulation could be accomplished by increasing the activity of enzymes already present or by increasing enzyme synthesis. Protein synthesis by platelets has not, to our knowledge, been demonstrated previously. In our experiments leucine- $\mathrm{U}-{ }^{14} \mathrm{C}$ was readily incorporated into the TCA-precipitable fraction, which was further purified by heating in TCA, by washing four times in TCA, and by extraction with lipid solvents. Furthermore, this incorporation was markedly inhibited by puromycin. We have assumed, therefore, that the leucine incorporation into TCA-precipitable material represents protein synthesis in the platelets. Further evidence to substantiate this assumption will be published elsewhere.

In studies intended to test the relationship between protein synthesis and the stimulation of glucose oxidation by thrombin, $0.1 \mathrm{mM}$ puromycin inhibited protein synthesis by more than $80 \%$ but had little effect on glucose oxidation in either untreated or thrombin-treated platelets; $1.0 \mathrm{mM}$ puromycin inhibited protein synthesis by $95 \%$, reduced oxidation in both untreated and treated cells, and lessened but did not obliterate stimulation by thrombin. The failure of almost complete inhibition of protein synthesis to prevent stimula- tion by thrombin suggests that the stimulation does not depend completely, if at all, on new enzyme formation and may instead be related to altered enzyme activity.

Enzyme activity could be altered by changes in the concentrations of cofactors or ions within the platelet. For example, ADP, which is known to inhibit hexokinase (39), is released from platelets when they are exposed to thrombin, and this release could result in an increased activity of platelet hexokinase. There is abundant evidence showing that cations are important to clot retraction. In the absence of calcium or magnesium, clot retraction does not occur (2). After the exposure of platelets to thrombin there are marked changes in the movement of cations into and out of the cell. Zieve, Gamble, and Jackson (36) showed that thrombin causes a greater permeability of the platelet membrane to potassium with resultant potassium loss from the cell. Grette (33) proposed that calcium ions enter the thrombin-treated platelet and trigger the release of intracellular contents. We found that addition of EDTA to the incubation mixture a few minutes after the addition of thrombin resulted in a potentiation of the stimulation of glucose oxidation by thrombin. Since EDTA added before thrombin did not enhance the stimulation by thrombin, it may be that the potentiation by EDTA depends upon the increased platelet permeability produced by thrombin. This interaction might further suggest that the mechanism by which thrombin stimulates glucose oxidation involves the loss or sequestration of intracellular divalent cations.

Thrombin and divalent cations are believed to act on the platelet in separate, successive steps (33, 40), which can be represented as follows: 1) thrombin + platelet $\rightarrow$ altered platelet; 2) $\mathrm{Ca}^{++}$ or $\mathrm{Mg}^{++}+$altered platelet $\rightarrow$ selective release of platelet contents and initiation of clot retraction. The findings of the present study suggest a possible third step in the sequence: 3 ) release of divalent cations from platelets $\rightarrow$ stimulation of glucose oxidation.

It is of interest to note that in platelets pretreated with EDTA thrombin apparently stimulated the hexose monophosphate pathway selectively. This stimulation contrasts with the stimulation of the Embden-Meyerhof pathway observed in the absence of EDTA or when EDTA was 
added after thrombin. The mechanism and significance of this alteration in response to thrombin are unknown.

\section{Summary}

1. Glucose oxidation by human platelets incubated in Krebs-Ringer bicarbonate buffer was measured by collection of ${ }^{14} \mathrm{CO}_{2}$ from glucose$1-{ }^{14} \mathrm{C}$ or glucose- $6-{ }^{14} \mathrm{C}$. Platelets oxidized glucose both by the Embden-Meyerhof pathway and by the hexose monophosphate pathway.

2. Thrombin caused platelets to increase the oxidation of glucose- $1-{ }^{14} \mathrm{C}$ and of glucose- $6-{ }^{14} \mathrm{C}$ in equal amounts. This was interpreted as a stimulation of the Embden-Meyerhof pathway of glucose oxidation.

3. In contrast to the prolonged stimulation of glucose oxidation by thrombin, the stimulation of lactate production was only short-lived.

4. Thrombin caused platelets to increase the oxidation of mannose- $-1-{ }^{14} \mathrm{C}$ and fructose- $\mathrm{U}^{14} \mathrm{C}$ but to decrease the oxidation of pyruvate- ${ }^{-14} \mathrm{C}$. These findings suggested that thrombin acts at a step earlier in the metabolic sequence of glucose oxidation than the entry of pyruvate.

5. In platelets pretreated with EDTA, thrombin stimulated the hexose monophosphate pathway rather than the Embden-Meyerhof pathway.

6. EDTA added after thrombin enhanced the stimulation of the Embden-Meyerhof pathway by thrombin.

7. Protein synthesis was demonstrated in platelets. Inhibition of this synthesis by puromycin did not eliminate the ability of thrombin to stimulate glucose oxidation.

\section{References}

1. Warshaw, A. L., L. Laster, and N. R. Shulman. The nature of thrombin stimulation of glucose oxidation by platelets. J. clin. Invest. 1966, 45, 1084.

2. Corn, M., D. P. Jackson, and C. L. Conley. Components of blood necessary for clot retraction. Bull. Johns Hopk. Hosp. 1960, 107, 90.

3. Quick, A. J., and C. V. Hussey. The mechanism of clot retraction. Science 1950, 112, 558.

4. Morse, E. E., D. P. Jackson, and C. L. Conley. Role of platelet fibrinogen in the reactions of platelets to thrombin. J. clin. Invest. 1965, 44, 809.

5. Schmid, H. J., D. P. Jackson, and C. L. Conley. Mechanism of action of thrombin on platelets. J. clin. Invest. 1962, 41, 543.
6. Lüscher, E. F. Viscous metamorphosis of blood platelets and clot retraction. Vox Sang. (Basel) 1956, 1, 133.

7. Budtz-Olsen, O. E. Clot Retraction. Springfield, I11., Charles C Thomas, 1951, p. 64.

8. Bettex-Galland, M., and E. F. Lüscher. Thrombosthenin, the contractile protein from blood platelets and its relation to other contractile proteins in Advances in Protein Chemistry, C. B. Anfinsen, Jr., M. L. Anson, J. T. Edsall, and F. M. Richards, Eds. New York, Academic Press, 1965, vol. 20, p. 1.

9. Born, G. V. R., and M. P. Esnouf. The breakdown of phospholipids and of other phosphorus compounds during coagulation of platelet-rich plasma in Blood Platelets, S. A. Johnson, R. W. Monto, J. W. Rebuck, and R. C. Horn, Jr., Eds. Boston, Little, Brown, 1961, p. 365.

10. Bounameaux, Y. Recherches sur le mécanisme de la rétraction du caillot et de la métamorphose visqueuse des plaquettes. Experientia (Basel) 1956, $12,355$.

11. Lüscher, E. F. Glukose als cofactor bei der Retraktion des Blutgerinnsels. Experientia (Basel) 1956, 12, 294.

12. Gross, R. Metabolic aspects of normal and pathological platelets in Blood Platelets, S. A. Johnson, R. W. Monto, J. W. Rebuck, and R. C. Horn, Jr., Eds. Boston, Little, Brown, 1961, p. 407.

13. Bettex-Galland, M., and E. F. Lüscher. Studies on the metabolism of human blood platelets in relation to clot retraction. Thrombos. Diathes. haemorrh. (Stuttg.) 1960, 4, 178.

14. Born, G. V. R. Changes in the distribution of phosphorus in platelet-rich plasma during clotting. Biochem. J. 1958, 68, 695.

15. Corn, M. Effect of thrombin on glycolysis of fresh and stored platelets. J. appl. Physiol. 1966, 21, 62.

16. Hussain, Q. Z., and T. F. Newcomb. Thrombin stimulation of platelet oxygen consumption rate. J. appl. Physiol. 1964, 19, 297.

17. Laki, K., and J. A. Gladner. Chemistry and physiology of the fibrinogen-fibrin transition. Physiol. Rev. 1964, 44, 127.

18. Johnson, J. F., and W. H. Seegers. Preparation, purification and assay of thrombin in The Coagulation of Blood, L. M. Tocantins, Ed. New York, Grune \& Stratton, 1955, p. 120.

19. Umbreit, W. W., R. H. Burris, and J. F. Stauffer. Manometric Techniques. Minneapolis, Burgess, 1957, p. 149.

20. Bruno, G. A., and J. E. Christian. Correction for quenching associated with liquid scintillation counting. Analyt. Chem. 1961, 33, 650.

21. Manchester, K. L., and F. G. Young. The effect of insulin on incorporation of amino acids into protein of normal rat diaphragm in vitro. Biochem. J. 1958, 70, 353. 
22. Barker, S. B., and W. H. Summerson. The colorimetric determination of lactic acid in biological material. J. biol. Chem. 1941, 138, 535.

23. Rodman, N. F., Jr., R. G. Mason, and K. M. Brinkhous. Some pathogenetic mechanisms of white thrombus formation: agglutination and self-destruction of the platelet. Fed. Proc. 1963, 22, 1356.

24. Sharp, A. A. Present status of platelet aggregation. New Engl. J. Med. 1965, 272, 89.

25. McLean, J. R., K. E. Maxwell, and D. Hertler. Fibrinogen and adenosine diphosphate-induced aggregation of platelets. Nature (Lond.) 1964, 202, 605.

26. De Vreker, G. G., and R. A. De Vreker. Aspects of platelet metabolism during aggregation. Rev. belge Path. 1965, 31, 79.

27. Warburg, O. Untersuchungen über die Oxydationsprozesse in Zellen. Münch. med. Wschr. 1911, 58, 289.

28. Endres, G., and F. Kubowitz. Stoffwechsel der Blutplättchen. Biochem. Z. 1927, 191, 395.

29. Luganova, I. S., I. F. Seits, and V. I. Teodorovich. Metabolism in human thrombocytes. Biochemistry 1958, 23, 379.

30. Waller, H. D., G. W. Löhr, F. Grignani, and R. Gross. Uber den Energiestoffwechsel normaler menschlicher Thrombozyten. Thrombos. Diathes. haemorrh. (Stuttg.) 1959, 3, 520.

31. Marcus, A. J., and M. B. Zucker. The Physiology of
Blood Platelets. New York, Grune \& Stratton, 1965, p. 7.

32. Campbell, E. W., W. J. Small, and W. Dameshek. Metabolic activity of human blood platelets. J. Lab. clin. Med. 1956, 47, 835.

33. Grette, K. Studies on the mechanism of thrombincatalyzed hemostatic reactions in blood platelets. Acta physiol. scand. 1962, 56 (suppl. 195).

34. Firkin, B. G., B. J. O'Neill, B. Dunstan, and R. Oldfield. The effect of incubation and storage on human platelet structure as studied by electron microscopy. Blood 1965, 25, 345.

35. Woodside, E. E., and W. Kocholaty. Carbohydrates of human and bovine platelets. Blood 1960, 16, 1173.

36. Zieve, P. D., J. L. Gamble, Jr., and D. P. Jackson. Effects of thrombin on the potassium and ATP content of platelets. J. clin. Invest. 1964, 43, 2063.

37. Sols, A. The hexokinase activity of the intestinal mucosa. Biochim. biophys. Acta (Amst.) 1956, $19,144$.

38. Sols, A., and R. K. Crane. Substrate specificity of brain hexokinase. J. biol. Chem. 1954, 210, 581.

39. Sols, A., and R. K. Crane. The inhibition of brain hexokinase by adenosinediphosphate and sulfhydryl reagents. J. biol. Chem. 1954, 206, 925.

40. Gaintner, J. R., D. P. Jackson, and C. L. Conley. Morphologic studies of clot retraction. Bull. Johns Hopk. Hosp. 1962, 111, 266. 